\title{
Herpes simplex virus and Alzheimer's disease: a search for virus DNA by spot hybridisation
}

\author{
GR TAYLOR, TJ CROW, DA MARKAKIS, R LOFTHOUSE, S NEELEY, GI CARTER \\ From the Division of Psychiatry, Clinical Research Centre, Harrow, Middlesex, UK
}

SUMMARY A sensitive hybridisation screening technique (spot hybridisation) was used to search post-mortem brain DNA extracts for herpes simplex I virus sequences in non-neurological controls, Alzheimer's disease cases and Herpes simplex virus infected mice. A reconstruction experiment showed that $0 \cdot 1$ herpes genome equivalents per cell could be detected in $100 \mu \mathrm{g}$ tissue extracts. Although herpes sequences were readily detected in infected mice, none of the human brains examined could be shown to contain such sequences.

It is well known that type I herpes simplex virus (HSV 1) is present in the trigeminal ganglia of man' and experimentally infected animals, ${ }^{2}$ but there are conflicting reports concerning the presence of HSV 1 in the human brain itself. Using solution hybridisation techniques Wetmur et $a l^{3}$ and Aulakh et $a l^{4}$ both reported no detectable HSV 1 sequences in human post-mortem brain material, each claiming a sensitivity of approximately 1 genome equivalent per 10 cells. However Fraser et al, ${ }^{5}$ using a filter hybridisation with a sensitivity claimed to be of 1 genome equivalent per 200 cells, reported the detection of HSV 1 DNA in the brains of several normal individuals and patients with neurological disease. In addition Sequeira et $\mathrm{l}^{6}$ reported the detection in in situ hybridisation of HSV 1 sequences in three of four elderly chronic psychiatric cases, but not in brain smears from 2 patients who had acute psychotic episodes. The occasional detection of HSV 1 immunoreactivity in human brain samples, including cases of Alzheimer's disease has also been reported..$^{-9}$

It has been speculated ${ }^{10}$ that Alzheimer-type dementia may result from chronic HSV 1 infection. The purpose of the present study was to investigate the distribution of HSV DNA in the CNS of Alzheimer's disease patients and controls.

\section{Materials and methods}

Plasmids pBR322 and pHSV 106, a pBR322 deriva-

Address for reprint requests: Dr GR Taylor, Clinical Research Centre, Watford Rd, Harrow, Middlesex, HA1 3UJ, UK

Received 7 February 1984 and in revised form 29 March 1984. Accepted 1 April 1984 tive containing a $3.4 \mathrm{~Kb}$ insert of HSV DNA including the thymidine kinase gene (BRL Ltd) were used to transform $E$ coli $\mathrm{HB} 101 .{ }^{\prime \prime}$ Ampicillin resistant colonies were grown in $100 \mathrm{ml}$ of $\mathrm{LB}$ broth and purified as described by Birnboim. ${ }^{12}$

Brain DNA was extracted from $100 \mathrm{mg}$ of tissue by homogenisation in $0.4 \mathrm{ml}$ of extraction buffer (150 mM NaCl; $100 \mathrm{mM}$ tris; $10 \mathrm{mM}$ EDTA, $1 \%$ SDS; $50 \mu \mathrm{g} / \mathrm{ml}$ proteinase $\mathrm{K}$ (pH 8). Samples were shaken at room temperature overnight, then extracted twice with phenol: chloroform: iso amyl alcohol (50:50:1). The aqueous phase was precipitated with 2 volumes of ethanol, the precipitate washed in $70 \%$ ethanol and then dissolved in $0.5 \mathrm{ml}$ STE buffer $(100 \mathrm{mM} \mathrm{NaCl} ; 10 \mathrm{mM}$ Tris; $1 \mathrm{mM}$ EDTA; pH 8). $20 \mu$ l of this solution was examined by agarose gel electrophoresis $(6 \mathrm{~V} / \mathrm{cm}$ for 6 hours in $0 \cdot 8 \%$ agarose with tris acetate buffer, $\mathrm{pH} 8 \cdot 3)$. RNA was removed by boiling in $0.1 \mathrm{M} \mathrm{NaOH}$ for 30 minutes followed by neutralisation with $\mathrm{HCl}$ and precipitation with 2 volumes of ethanol. The precipitate was redissolved in $1.5 \mathrm{M} \mathrm{NaCl}, 0.15 \mathrm{M}$ sodium citrate $(10 \times \mathrm{SSC}, \mathrm{pH} 7 \cdot 2)$ and DNA concentration estimated using the equation [DNA] $\mathrm{mg} / \mathrm{ml}=$ OD260 nm/22.

The DNA solution was held in a boiling water bath for 5 minutes prior to filtration in duplicate on to prewetted nitrocellulose (Schleicher and Schuell Ltd) or nylon 66 (Biodyne A, Pall Ltd) membrane using a 96 well filtration unit (BRL Ltd). Filters were air dried and baked for 2 hours at $80^{\circ} \mathrm{C}$.

Molecular hybridisation was as described by Jeffreys $^{13}$ using a prehybridisation solution of $5 \times$ Denhardt's solution $(0.2 \%$ polyvinyl pyrolidine; $0.2 \%$ ficol; $0.2 \%$ bovine serum albumin in $1 \times$ SSC), $0 \cdot 1 \%$ SDS, $9 \%$ dextran sulphate and 100 
$\mu \mathrm{g} / \mathrm{ml}$ denatured salmon DNA at $65^{\circ} \mathrm{C}$.

DNA probes were labelled by nick translation ${ }^{14}$ using ${ }^{32} \mathrm{P}$ dCTP with a specific activity of $400 \mathrm{Ci} /$ mole (Amersham). The specific activity of the plasmid probes was $2-3 \times 10^{8} \mathrm{cpm} / \mu \mathrm{g}$ ). Human DNA was labelled to a lower specific activity $\left(5 \times 10^{5}-1\right.$ $\times 10^{6} \mathrm{cpm} / \mu \mathrm{g}$ ).

After denaturation by boiling the probe was added to fresh hybridisation solution to give a final concentration of $10 \mathrm{ng} / \mathrm{ml}$. Filters were incubated in the hybridisation solution at $65^{\circ} \mathrm{C}$ for 16 hours, followed by $3 \times 30$ minute washes in hybridisation solution without probe and without dextran sulphate, then $3 \times 30$ minute washes in a solution containing $0 \cdot 1 \times$ SSC, $50 \mu \mathrm{g} / \mathrm{ml}$ solution DNA and $0.1 \%$ SDS. The filters were blotted, dried and autoradiographed using Kodak XS films and Ilford Rapide intensifying screens at $-70^{\circ} \mathrm{C}$ for 36 hours.

Three sets of hybridisation experiments were performed using the same samples. First a negative control using pBR322, next after washing the filters pHSV106 was used to detect HSV 1 DNA, and finally human DNA retention was checked by probing with labelled human DNA.

\section{Results}

The preservation of DNA in the necropsy samples was confirmed by electrophoresis (fig 1a). A typical set of extracts had a substantial proportion of the
DNA present as large fragments ( $>23$ kilobase pairs) with some smaller components including some RNA. The mean yield of DNA was $0.5 \mu \mathrm{g}$ per mg of tissue.

Plasmids prepared by the rapid alkaline extraction method were found to be predominantly supercoiled molecules (fig 1b), which could be labelled with high efficiency using in vitro nick translation without further purification.

Successful binding and retention of DNA to filters was evaluated by the final hybridisation experiment using labelled human DNA. Comparison with a series of standards enabled an estimate of the quantity of bound DNA to be made (fig 2). Cases where less than microgram quantities of DNA were retained on the filter, or where non-specific binding of pBR322 was observed were not included in the analysis of results. The table summarises the number of samples which were included in the analysis of results. The total of 112 samples include 57 samples from nine non-neurological control patients and 55 from eight cases of dementia of the Alzheimer type.

Nitrocellulose filters gave a slightly better retention of DNA at higher concentrations than nylon filters. Figure 3 shows the result of a filtration experiment in which $100 \mu \mathrm{l}$ samples from the same stock of denatured human DNA in $10 \times$ SSC were filtered through two superimposed membranes, either nylon or nitrocellulose. Nearly all of the $5 \mu \mathrm{g}$ standard was retained by the first (upper) nitrocellulose mem

Fig 1 Agarose gel electrophoresis of nucleic acids. (a) Total undigested nucleic acid extract from a typical set of necropsy brains used in this study (tracks 1-14). Track 15 is a $\lambda$ hind III digest, the largest (upper) fragment has a size of approximately 23 kilobase pairs.

Electrophoresis was $6 \mathrm{~V} / \mathrm{cm}$ and $\mathrm{pH} 8.3$ for 4 hours in $1 \%$ agarose. (b) Plasmids used in this study: track 1 is a $\lambda$ hind III digest, track 2 is pHSV 106 and track 3 is pBR322. Electrophoresis was for 16 hours at $\mathrm{pH} 8.3$ in $0.8 \%$ agarose. 


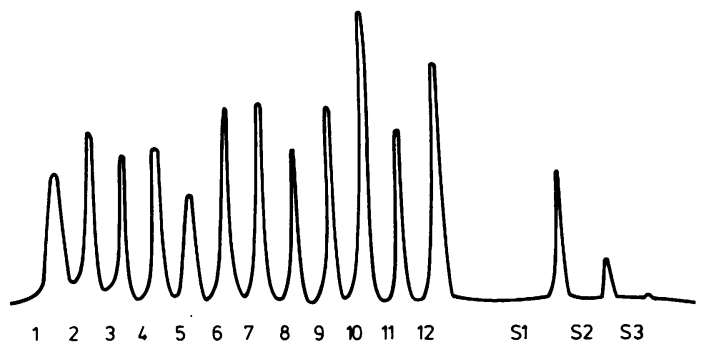

Fig 2 DNA retention by filters. After hybridisation with pBR322 and pHSV 106 the filters were washed and hybridised with ${ }^{32} \mathrm{P}$ human DNA (see text for details). The intensity of autoradiograph spots was compared to a series of standards $(\mathrm{S} 1=1 \mu \mathrm{g}, \mathrm{S2}-100 \mathrm{ng}, \mathrm{S3}=10 \mathrm{ng}$ human $D N A)$ to obtain an estimate of the amount of DNA bound. Numbers 1-12 are a typical set of extracts used in this study.

brane, whereas a substantial amount leaked through the first nylon membrane when either $5 \mu \mathrm{g}$ or $1 \mu \mathrm{g}$ of DNA was filtered. For this reason we used nitro- cellulose membranes in the rest of this study.

The sensitivity and specificity of hybridisation was examined using a series of controls. Figure 4a shows the result of a hybridisation reaction using pHSV 106 as a probe for homologous sequences in filter bound pBR322. A strong hybridisation signal was seen, and as little as $2 \mathrm{pg}$ of pBR322 could be detected.

Next the ability of pHSV 106 to detect HSV 1 sequences in infected brain tissue was confirmed using control and infected mouse brain DNA extracts. The infected mouse brain homogenate contained $1 \times 10^{2}$ plaque forming units $/ \mathrm{mg}$ of HSV 1 after freezing and thawing. $10 \mathrm{mg}$ of this homogenate was extracted and the DNA extract was diluted in a series of 10 fold steps. Figure $4 \mathrm{~b}$ shows the result of hybridisation with labelled pHSV 106. A signal was clearly detectable in the rows 3 and 4 (neat and $10^{-1}$ ) equivalent to 10 and 1 plaque forming unit (pfu) of HSV, and a signal slightly higher than background was visible at $10^{-3}$ It was not

Table Post-mortem brain areas used in hybridisation experiment

\begin{tabular}{|c|c|c|c|c|c|c|c|c|c|c|}
\hline Control & 1 & 2 & 3 & 4 & 5 & 6 & 7 & 8 & 9 & Total \\
\hline Substantia nigra & + & + & + & + & + & - & + & + & + & 8 \\
\hline Putamen & + & + & + & + & + & + & + & + & + & 9 \\
\hline Globus pallidus & + & + & - & + & + & + & + & + & + & 8 \\
\hline Caudate & + & + & + & + & + & + & - & - & + & 7 \\
\hline Olfactory tubercle & + & + & + & + & + & - & + & - & + & 7 \\
\hline Temporal cortex & + & + & + & + & + & - & - & + & - & 6 \\
\hline Amygdala & + & + & + & + & + & + & + & + & - & 8 \\
\hline Hippocampus & + & + & - & + & - & - & + & - & - & 4 \\
\hline Dementia & 1 & 2 & 3 & 4 & 5 & 6 & 7 & 8 & & Total \\
\hline Substantia nigra & + & - & + & + & + & + & + & + & & 7 \\
\hline Putamen & + & + & + & + & + & + & + & - & & 7 \\
\hline Globus pallidus & + & + & + & + & + & + & + & + & & 8 \\
\hline Caudate & + & - & + & + & + & + & + & + & & 7 \\
\hline Olfactory tubercle & + & + & + & + & + & + & + & + & & 8 \\
\hline Temporal cortex & + & + & + & + & + & + & + & + & & 8 \\
\hline Amygdala & + & - & + & - & + & - & + & - & & 4 \\
\hline Hippocampus & + & - & + & - & + & + & + & + & & 6 \\
\hline
\end{tabular}

Controls $n=9$, mean age $=75( \pm 8)$ yrs, sex ratio $6 \mathrm{M} ; 3 \mathrm{~F}$. Dementia $\mathrm{N}=8$, mean age $=71( \pm 10)$ yrs, sex ratio $4 \mathrm{M} ; 4 \mathrm{~F}$.

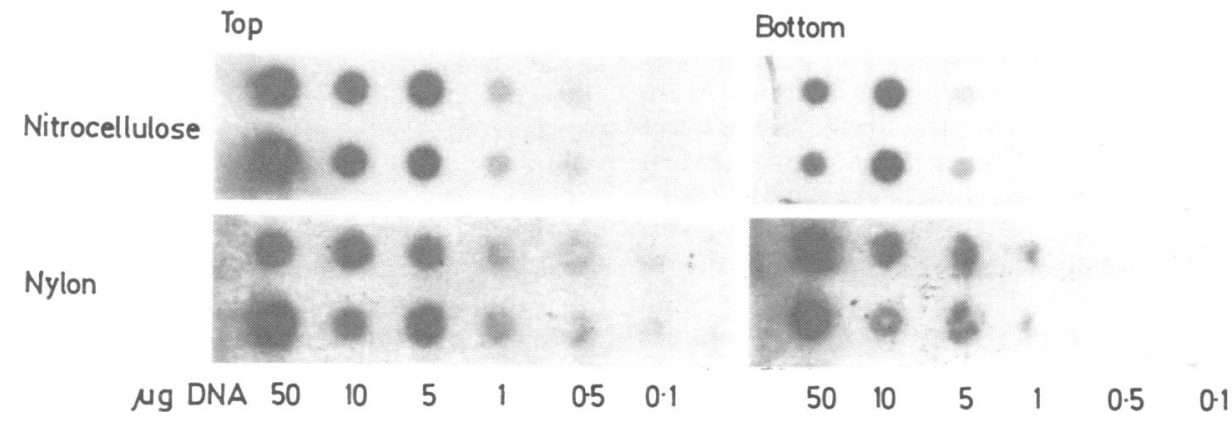

Fig 3 Comparison of the retention of DNA by nylon and nitrocellulose. Denatured human DNA solutions were filtered through two membranes and after baking the membranes retention of DNA was checked by hybridisation at $5 \mu \mathrm{g}$ per spot the membranes were both saturated, and above this DNA leaked through to the lower membrane. Under the conditions used (see methods) the performance of nitrocellulose was superior, giving sharper spots and better retention at higher concentrations. 


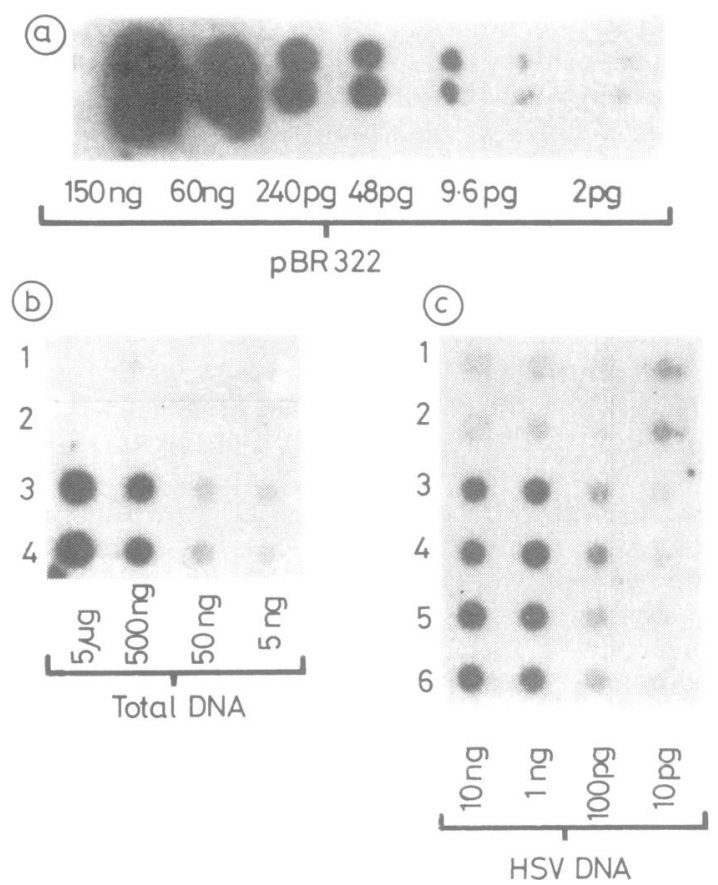

Fig 4 Sensitivity and specificity of hybridisation (a) Detection of pBR322 sequences by pHSV 106 (b) Detection of HSV sequences in infected mouse brain homogenates by pHSV 106. Rows 1 and 2 control mouse brain, rows 3 and $4 \mathrm{HSV}$ infected mouse brain (c) Detection of HSV DNA by pHSV 106. Rows 1 and 2: DNA extract from a human cortex white matter only $(5 \mu \mathrm{g})$, rows 3 and 4: serial dilutions of HSV DNA, rows 5 and 6: serial dilutions of HSV DNA mixed with $5 \mu \mathrm{g}$ of human DNA.

possible to interpret these results in terms of HSV DNA since the DNA to infectivity ratio in the infected brain homogenates is not known. A direct quantitative measure was obtained using DNA extracted from glycerol gradient purified HSV 1 (fig 4c). The HSV DNA concentration was measured by ultraviolet absorption and serial dilutions were made and filtered either alone or in the presence of $5 \mu \mathrm{g}$ of DNA extracted from human cortex. Most cortex samples alone gave low background signals, and HSV DNA could be detected at $100 \mathrm{pg}$ levels with or without additional host material.

When the control and Alzheimer's disease brain samples were hybridised with pBR322, two samples gave a hybridisation signal. The reason for this occasional non-specific hybridisation is not known, but it occurred repeatedly and always with the same samples. Those samples were excluded from the analysis of results and are not shown in the table. Subsequent hybridisation with pHSV 106 did not produce any detectable binding in any of the human samples.

\section{Discussion}

Since we were able to detect 100 pg of HSV 1 DNA in the presence of $1-5 \mu \mathrm{g}$ of human DNA on a filter, we estimate the limits of sensitivity to be between $0 \cdot 1$ and $0.5 \mathrm{HSV}$ genome equivalents per cell. Fraser et $a l^{5}$ reported the detection of HSV DNA sequences using a probe similar or identical to pHSV 106, containing a 3.4 kilobase Bam $\mathrm{H} 1$ insert including the HSV thymidine kinase gene, so in studies using that probe it is likely that our techniques were of comparable sensitivity. The claimed sensitivity of 1 genome per 200 cells presumably applied to studies using either whole HSV sequences or much larger cloned fragments. In this case, as in the study by Sequeira et $a^{6}$ there is a risk of false positive findings due to the hybridisation between mammalian DNA and HSV short terminal repeated sequences. ${ }^{15}$ On the basis of this study there is no evidence of replicating HSV in the human central nervous system, either in Alzheimer's disease patients or in non-neurological controls. This included areas of the limbic system (amygdala, hippocampus, temporal cortex) where HSV replicates during acute encephalitis ${ }^{16}$ and which may be associated with the pathology of Alzheimer's disease. ${ }^{17}$

The possibility cannot be excluded that latent HSV could be sporadically reactivated, perhaps from another site, or that we failed to detect a small number of latently infected cells. Small numbers of isolated cells carrying the HSV genome may only be detectable using in situ hybridisation, where large numbers of individual cells can be examined. As the brain is a large organ, a systematic survey would be a time consuming endeavour, but there are no alternative methods offering a sensitivity comparable to hybridisation. Although Morawetz et al ${ }^{18}$ report a high success rate in the cultivation of HSV from biopsies of acute HSV encephalitis, direct infectious assay has been less successful when applied to latently infected CNS tissue. Cabrera et al $^{19}$ isolated HSV from $5 \%$ of infected mouse brains after the acute phase, yet could detect HSV sequences in $30 \%$ of the brains. Similarly Rock and Fraser $^{20}$ could detect HSV sequences in mouse brain stem 2 months post infection, but were not able to grow viruses from brain stem explants.

In conclusion, our results do not support the findings of Fraser $\mathrm{et} \mathrm{al}^{5}$ that HSV DNA is commonly found in the human CNS; in the brains we examined HSV DNA was either absent or present at a very low level. However by analogy with mouse studies ${ }^{20}$ there are other areas that might be expected to harbour virus sequences after a CNS infection, such as the brain stem. It may be fruitful to look in these 
areas and employ techniques such as immunocytochemistry, which has been reported to detect HSV antigenicity in brains, both non-neurological and Alzheimer's disease cases, ${ }^{9}$ in addition to molecular hybridisation.

\section{References}

' Bastian, FO, Rabson, AS Yee, CL, Tralka, TS. Herpes virus hominis: isolation from human trigeminal ganglion. Science 1972;178:305-7.

2 Stevens, JG Cook ML. Latent herpes simplex virus in spinal ganglia of mice. Science 1971;173:843-5.

${ }^{3}$ Wetmur JG, Schwartz J, Elizon TS. Nucleic acid homology, studies of viral nucleic acids in idiopathic Parkinsons's disease. Arch Neurol 1979;36:462-4.

${ }^{4}$ Aulakh, GS, Albrecht, P, Tourtellotte, WW. Search for cytomegalovirus and herpes simplex virus genetic information in multiple sclerosis. Neurology (Minneap) 1980;30:530-2.

s Fraser, NW, Lawrence WC, Wrobleska Z, Gelden DH, Koprowski H. Herpes simplex type I DNA in human brain tissue. Proc Nat Acad Sci 1981;78:6461-5.

- Sequira LW, Jennings LC, Carasco LH, Lord M, Curry A, Sutton RNP. Detection of herpes simplex viral genome in brain tissue. Lancet 1979;ii:609-12.

7 Mann DMA, Yates PO, Davies JS, Hawkes J. Viruses, parkinsonism and Alzheimer's disease. J Neurol Neurosurg Psychiatry 1981;44:651.

${ }^{8}$ Esiri, MM. Herpes simplex encephalitis: an immunohistological study of the distribution of viral antigen within the brain. J Neurol Sci 1982;54:209-26.

${ }^{9}$ Mann DMA, Tinkler AM, Yates, PO. Neurological disease and herpes simplex virus. Acta Neuropathol (Berl) 1983;60:24-8.
${ }^{10}$ Ball MJ. Neuronal and lymphocytic populations in human trigeminal ganglia: implications for aging and for latent virus. Neuropathol Appl Neurobiol 1982;8: 177-87.

"Lederberg EM, Cohen SN. Transformation of Salmonella typhomurium by plasmid deoxyribonucleic acid. J Bacteriol 1982;119:1072-4.

${ }^{12}$ Birnboim HC. A rapid alkaline extraction method for the isolation of plasmid DNA. Methods Enzymol, Wu, R., Grossman L, Moldave K. (eds.), 1983;100:243-54.

13 Jeffreys AJ. DNA sequence variants in the Gy-, Ay-, S and beta-globin genes of man. Cell 1979;18:1-10.

${ }^{14}$ Rigby, PJW, Dieckmann M, Rhodes C. Berg P. Labelling deoxyribonucleic acid to high specific activity by in vitro nick translation with DNA polymerase $1 . J$ Mol Biol 1977;113:237-51.

is Puga A, Cantim EM, Notkins AL. Homology between murine and human cellular DNA sequences and the terminal repetition of the $S$ component of herpes simplex virus type I DNA. Cell 1982;31:81-7.

${ }^{16}$ Esiri, MM. Viruses and Alzheimer's disease. J Neurol Neurosurg Psychiatry 1982;45: 759.

${ }^{17}$ Ball, MJ. Limbic predilection in Alzheimer dementia: is reactivated herpes virus involved? Can J Neurol Sci 1982;9:303-6.

${ }^{18}$ Morawetz, RB, Whittey RJ. Murphy D. Experience with brain biopsy for suspected herpes encephalitis: a review of forty consecutive cases. Neurosurgery $1983 ; 12: 654-7$.

${ }^{19}$ Cabrera CV, Wohlenberg C, Openshaw H, Rey Mendez M, Puga A, Notkins AL. Herpes simplex virus DNA sequences in the CNS of latently infected mice. Nature 1980; 288: 288-90.

${ }^{20}$ Rock DL, Fraser NW. Detection of HSV-1 genome in central nervous system of latently infected mice. Nature 1983;302:523-5. 